\title{
ANALISIS KENDALI PD PLUS GRAVITY UNTUK PERANGKAT PENGATUR POSISI SUMBER ION DECY-13
}

\author{
Saefurrochman \\ PSTA-BATAN, Kawasan BATN Yogyakarta, Depok, Sleman, Yogyakarta, \\ saefurrochman@batan.go.id
}

\begin{abstract}
ABSTRAK
ANALISIS KENDALI PD PLUS GRAVITY UNTUK PERANGKAT PENGATUR POSISI SUMBER ION DECY-13. Arus proton DECY-13 yang optimal dapat tercapai dengan salah satu cara yaitu dengan mengatur posisi sumber ion yang akurat. Untuk itu dibutuhkan sebuah perangkat pengatur posisi yang mampu menggerakkan seluruh bagian sumber ion (termasuk tangkai dan kelongsong tangkai). Konstruksi dari perangkat pengatur posisi ini memiliki kesamaan dengan manipulator yang memiliki dua buah link. Pada penelitian ini disimulasikan kendali posisi menggunakan pengendali $P D$ plus gravity untuk perangkat pengatur posisi sumber ion DECY-13 yang akan dibandingkan dengan pengendali PD. Simulasi dilakukan menggunakan program Simulink Matlab. Penelitian ini ditekankan pada penalaan nilai $K_{p}$ dan $K_{d}$ yang sederhana yaitu dengan cara memvariasi frekuensinya. Jangkauan frekuensi dibatasi antara $0,025 \mathrm{~Hz}$ hingga $10 \mathrm{KHz}$. Dengan membandingkan frekuensinya, dapat dilihat tanggapan kendali dari perangkat tersebut berupa overshoot, rise time serta settling time dan kinerjanya yang diwakili oleh nilai ISE, IAE dan ITAE. Dari hasil simulasi dapat disimpulkan bahwa, secara umum perangkat pengatur posisi sumber ion DECY-13 dengan pengendali $P D$ plus gravity memiliki tanggapan dan kinerja yang relatif lebih baik dibandingkan dengan pengendali PD, khususnya parameter IAE dan ITAE. Frekuensi $500 \mathrm{~Hz}$ dipilih untuk menala $K_{p}$ dan $K_{d}$. Frekuensi ini dipilih, karena dianggap optimal untuk mendapatkan tanggapan yang paling cepat dan kinerja yang paling baik.
\end{abstract}

Kata kunci: DECY-13, sumber ion, pengendali PD, pengendali PD plus gravity, frekuensi.

\begin{abstract}
ANALYSIS OF PD PLUS GRAVITY CONTROLLER FOR THE POSITION CONTROL OF DECY13 ION SOURCE. The optimum proton current of DECY-13 can be obtained by controlling the position of ion source accurately. Here, the position control device is needed to drive all parts of ion source. It is seen that the construction of the device is similar to manipulator with two links. In the experiment, position control with $P D$ plus gravity was simulated for the position control apparatus of DECY-13 ion source and it was compared with conventional PD controller. It was simulated by using Simulink Matlab software. The simple tuning of $K_{p}$ dan $K_{d}$ was the priority of this simulation. It was conducted by varying of its frequency. The range of frequency was limited between $0.025 \mathrm{~Hz}$ until $10 \mathrm{KHz}$. Based on the frequency comparison, the response and performance of the controller for the device could be observed. This response included: overshoot, rise time and settling time and also its performance was represented by ISE, IAE and ITAE.The simulation results show that generally, the response and performance PD plus gravity controller are better than conventional PD controller. The frequency of $500 \mathrm{~Hz}$ is chosen to tune $K_{p}$ and $K_{d}$. This frequency is an optimum frequency to obtain the fastest response and the best performance.
\end{abstract}

Key words: DECY-13, ion source, PD controller, PD plus gravity controller,frekwensi.

\section{PENDAHULUAN}

Pusat Teknologi Akselerator dan Proses Bahan-BATAN, Yogyakarta sebagai satu- satunya institusi akselerator (pusat rancangbangun alat pemercepat partikel) di Indonesia mencoba menjawab tantangan tersebut dengan memulai kegiatan rancangbangun siklotron "khas" Indonesia yang 
diberi nama DECY-13 (Design of Experimental Cyclotron in Yogyakarta-13 MeV). Kegiatan ini telah tertuang dalam Renstra BATAN 20102014 [1].

Berdasarkan rancangan konseptual, akan didesain sebuah siklotron proton untuk fasilitas PET dengan energi dan arus berkas proton 13 $\mathrm{MeV} / 50 \mu \mathrm{A}$. Sumber ion merupakan salah satu komponen utama. Sumber ion bertipe PIG dengan arus keluaran $100 \mu \mathrm{A}$. Posisi sumber ion adalah radial terhadap sisi tangki siklotron [2].

Untuk mendapatkan arus proton optimal, sumber ion dilengkapi dengan perangkat pengatur posisi.Perangkat pengatur posisi dirancang berdasarkan desain sumber ion. Sumber ion DECY-13 memiliki konstruksi head yang statis, sehingga dibutuhkan sebuah sistem elektromekanik sebagai pengatur posisi yang mampu menggerakkan seluruh bagian sumber ion (termasuk tangkai dan kelongsong tangkai). Prinsip kerja perangkat pengatur posisi sumber ion memiliki kesamaan dengan prinsip kerja manipulator.

Penelitian di bidang manipulator sudah cukup banyak dilakukan. Algoritma PD dan modifikasi PD merupakan salah satu jenis pengendali paling sering digunakan oleh peneliti, selain jaringan syaraf tiruan (JST) [3], fuzzy [4], adaptive force control [5], PID [6]. Permasalahan yang sering muncul dalam kendali PD adalah penalaan $K_{p}$ dan $K_{d}$ yang bersifat trial and error.

Kendali PD dengan kompensasi gravitasi dimanfaatkan secara online untuk mengendalikan robot manipulator dengan link yang fleksibel[7]. Kompensasi gravitasi secara online dilakukan dengan mengestimasi torsi gravitasi pada sebuah modifikasi gravity-biased dari deformasi link yang dikehendaki berdasarkan pada variabel joint. Sebuah kendali PD menggunakan kompensasi gravitasi dengan sebuah tingkat konvergensi finite-time yang digunakan untuk robot manipulator, sehingga diperoleh kecepatan tinggi dan posisi dengan presisi tinggi [8]. Terdapat sedikit kekurangan dalam penelitian ini yaitu penalaan $K_{p}$ dan $K_{d}$ bersifat trial and error.

Masalah lain yang muncul adalah penalaan $K_{p}$ dan $K_{d}$.yang tidak sederhana. kendali PD diusulkan untuk sebuah manipulator dengan link tunggal yang fleksibel[9]. Kendali ini disusun berdasarkan pada teori Lyapunov. Namun metode ini memiliki persamaan yang relatif kompleks dan dalam menentukan $K_{p}$ dan $K_{d}$.masih belum sederhana [9]. Tiga buah pendekatan kendali saturating $P D$ telah dikembangkan [10] dengan memanfaatkan decimal fraction power dari error posisi, pendekatan tersebut mampu mencapai tingkat konvergensi yang relatif lebih cepat. Perhitungan parameter $K_{p}$ dan $K_{d}$ relatif kompleks. Permasalahan penalaan untuk kendali PD diselesaikan dengan gravity compensation yang diaplikasikan pada sebuah robot 3-DOF [11]. Kendali tersebut terbukti stabil dan memiliki respon yang cepat. Dalam penelitian ini telah dilakukan penghitungan secara analitik parameter $K_{p}$ dan $K_{d}$. Namun penghitungan tersebut masih belum sederhana.

Dalam peneltian ini, kendali $P D$ plus gravity (PD dengan kompensasi gravitasi) dipilih dikarenakan memiliki konsep yang sederhana dan telah dibuktikan kestabilan dengan Lyapunov. Selain itu metode tersebut memiliki komputasi yang sederhana. Pada penelitian ini diusulkan penalaan nilai $K_{p}$ dan $K_{d}$ yang didasarkan pada pendekatan penalaan orde dua dengan kondisi critical damping $(\zeta=$ 1) dengan memvariasi frekuensi.

Makalah ini tersusun dari pendahuluan, penjelasan mengenai perangkat pengatur posisi sumber ion DECY-13, metodologi penelitian, pemodelan dan perancangan kendali, hasil dan pembahasan serta kesimpulan.

\section{PERANGKAT PENGATUR POSISI SUMBER ION DECY-13}

Perangkat pengatur posisi sumber ion berfungsi untuk mengatur posisi sumber ion di dalam ruang tabung siklotron agar dapat menghasilkan karakteristik berkas ion yang optimal.

Posisi sumber ion memiliki korelasi dengan optimasi berkas proton [12]. Posisi sumber ion menjadi salah satu faktor penting untuk mendapatkan berkas proton yang optimal. Untuk mendapatkan posisi sumber ion yang diinginkan, maka dibutuhkan sebuah perangkat pengatur posisi yang mampu menggerakkan seluruh bagian sumber ion (termasuk tangkai dan kelongsong tangkai). Perancangan perangkat pengatur posisi sumber ion harus disesuaikan dengan desain sumber ion, dimana sumber ion yang digunakan pada siklotron DECY-13 memiliki konstruksi head yang statis. 
Gambar 1 adalah perangkat pengatur posisi sumber ion DECY-13. Perangkat tersebut bergerak ketiga arah yang berbeda yaitu arah pergerakan maju-mundur, kanan-kiri dan atasbawah. Untuk mempermudah konstruksi, maka kedua arah pergerakan tersebut (arah pergerakan kanan-kiri dan atas-bawah) digabung menjadi satu oleh sendi kombinasi [13]. Hal ini menjadikan dinamika dari kedua arah pergerakan tersebut relatif lebih kompleks dibandingkan dengan arah pergerakan majumundur, sehingga diperlukan sebuah kendali. Konstruksi dari kedua arah pergerakan tersebut (kanan kiri dan atas bawah) mirip manipulator yang memiliki dua buah link, dimana link 1 relatif lebih pendek daripada link 2.
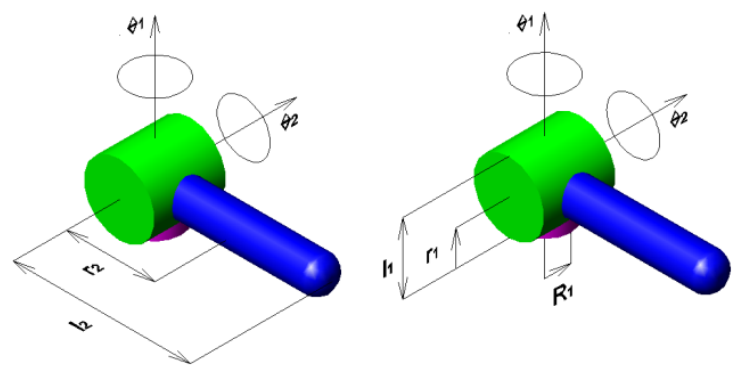

Gambar. 1. Perangkat pengatur posisi sumber ion DECY-13

\section{METODOLOGI}

Dalam penelitian ini alat dan bahan yang digunakan meliputi perangkat mekanik pengatur posisi sumber ion DECY-13, sebuah laptop dengan processor Core i3, yang dilengkapi dengan perangkat lunak Matlab dan CAD.

\section{Langkah pemodelan}

Sebelum pemodelan dilakukan, maka perlu dipelajari blok diagram kendali posisi dari perangkat pengatur posisi sumber ion DECY-13 seperti yang terlihat pada Gambar 2 .

Pada Gambar 2 terlihat bahwa sistem memiliki dua buah input yaitu posisi link 1 dan link 2. Error dari masing-masing link menjadi masukan bagi kendali. Pada kendali PD plus gravity, keluaran sinyal kendali PD akan ditambah dengan gravity dan keluarannya akan mengatur torsi perangkat pengatur posisi sumber ion. Dengan mengatur torsinya, maka posisi sumber ion juga berubah sesuai dengan masukan.

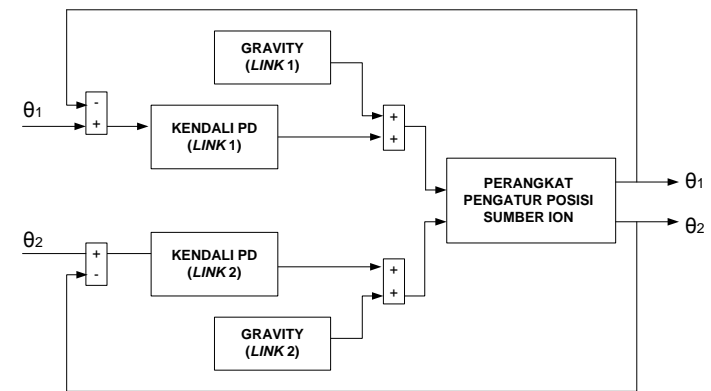

Gambar. 2. Kendali posisi dari perangkat pengatur posisi sumber ion DECY-13 dengan jenis pengendali PD plus gravity

Gambar 3 merupakan langkah dalam pembuatan model dari perangkat pengatur posisi sumber ion DECY-13.

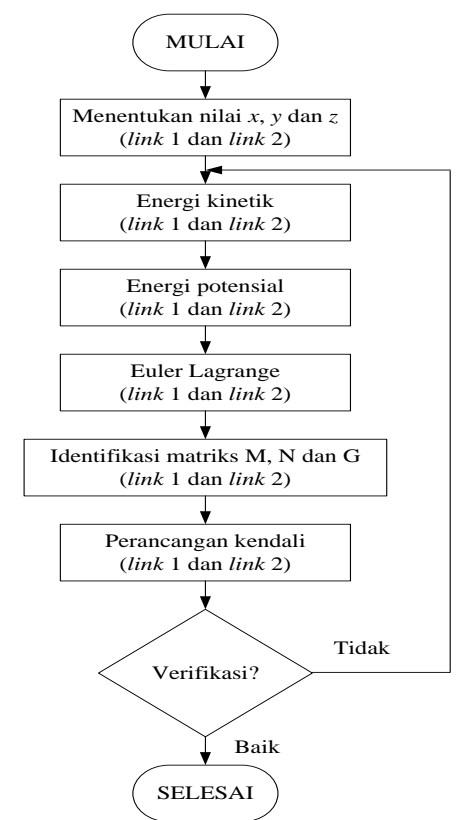

Gambar. 3. Langkah pemodelan perangkat pengatur posisi sumber ion DECY-13

Langkah awal pemodelan adalah menentukan nilai $x, y$ dan $z$ untuk link 1 dan link 2. Berdasarkan nilai $x, y$ dan $z$, dapat ditentukan energi kinetik dan potensial semua link. Dengan bantuan rumus Euler Lagrange akan diperoleh gaya yang dibangkitkan pada sebuah joint (torsi). Matriks torsi untuk link 1 dan link 2 tersebut akan diidentifikasi sebagai matriks $M$, $N$ dan $G$. Langkah selanjutnya dari pemodelan adalah perancangan kendali yang dipilih berdasarkan literature review. Setelah dilakukan pemodelan dan perancangan, maka dilakukan verifikasi terhadap hasilnya. Apabila terdapat kesalahan, maka akan dilakukan penghitungan ulang terhadap energi kinetik dan 
langkah-langkah berikutnya. Hal ini dapat dilihat pada Gambar 3.

\section{Simulasi}

Setelah dilakukan pemodelan, tahap berikutnya adalah membuat blok-blok pada Simulink yang didasarkan hasil dari pemodelan perangkat pengatur posisi sumber ion DECY-13 dan blok diagram Kemudian setelah blok-blok tersebut selesai disusun, maka simulasi akan dilakukan.

Simulasi dilakukan selama 50 detik dengan memvariasi beberapa frekuensi dari jangkau frekuensi $0,025 \mathrm{~Hz}$ hingga $10 \mathrm{KHz}$. Dengan memvariasi frekuensi, itu berarti nilai $K_{p}$ dan $K_{d}$ juga berubah. Pada penelitian ini variasi frekuensi tersebut diaplikasikan untuk simulasi dengan pengendali $P D$ plus gravity dan PD sebagai pembanding, baik pada kondisi tanpa beban maupun dengan beban.

\section{Analisis hasil simulasi}

Langkah selanjutnya adalah menganalisis hasil simulasi. Analisis dilakukan dengan menilai kinerja dari setiap sistem kendali yang dirancang. Sistem kendali yang dirancang meliputi $P D$ plus gravity yang akan dibandingkan dengan PD. Pengendali tersebut diintegrasikan pada plant sistem kendali posisi dari perangkat pengatur posisi sumber ion.

Untuk kategori tanpa gangguan dan dengan gangguan, terdapat tiga parameter kinerja yaitu overshoot, settling time dan nilai steady state error yang direpresentasikan oleh ISE, IAE dan ITAE.

Pada sistem ini, overshoot dan settling time diharapkan minimal karena berkaitan dengan tingkat sensitivitas sistem terhadap gangguan dan seberapa cepat sistem kembali pada kondisi tunak. Selain itu kinerja seperti ISE, IAE dan ITAE diharapkan minimal..

Setelah dilakukan analisis, maka dilakukan verifikasi terhadap hasilnya. Apabila terdapat kesalahan, maka akan dilakukan pengecekan ulang dan perbaikan terhadap pemodelan dan langkah-langkah berikutnya.

\section{PEMODELAN DAN PERANCANGAN KENDALI}

Pemodelan
Untuk mendesain sebuah manipulator dibutuhkan sebuah model matematika yang merepresentasikan dinamika dari persamaan gerak manipulator tersebut. Secara umum model dinamik dari sebuah manipulator ditunjukkan oleh persamaan (1)

$$
M(q) \ddot{q}+C(q, \dot{q}) \dot{q}+G(q)=\tau
$$

Langkah pertama adalah menentukan posisi dari link 1 dan link 2 seperti yang terlihat pada persamaan (2) hingga (8)

$$
\begin{gathered}
x_{1}=r_{1} \cos \theta_{1} \\
y_{1}=r_{1} \sin \theta_{1} \\
z_{1}=0 \\
x_{2}=l_{1} \cdot \cos \theta_{1}+r_{2} \cdot \sin \theta_{1} \cdot \cos \theta_{2} \\
y_{2}=l_{1} \cdot \sin \theta_{1}+r_{2} \cdot \cos \theta_{1} \cdot \cos \theta_{2} \\
z_{2}=r_{2} \cdot \sin \theta_{2}
\end{gathered}
$$

Posisi link 1 dan link 2 digunakan untuk menghitung energi kinetik dan energi potensial dari masing-masing link. Energi kinetik link 1 dan link 2 ditunjukkan oleh persamaan (8) dan (9), sedangkan energi potensial link 1 dan link 2 ditunjukkan oleh persamaan (10) dan (11).

$$
\begin{gathered}
T_{1}=\frac{1}{2} \cdot m_{1} \cdot \dot{\theta}_{1}{ }^{2} \cdot r_{1}{ }^{2}+\frac{1}{2} \cdot I_{1} \cdot \dot{\theta}_{1}^{2} \\
T_{2}=\frac{1}{2} \cdot m_{2} \cdot l_{1}{ }^{2} \cdot \dot{\theta}_{1}{ }^{2} \\
+\frac{1}{2} \cdot m_{2} \cdot r_{2}{ }^{2} \cdot \dot{\theta}_{1}{ }^{2} \cdot \cos ^{2} \theta_{2} \\
+\frac{1}{2} \cdot m_{2} \cdot r_{2}{ }^{2} \cdot \dot{\theta}_{2}{ }^{2} \\
+2 \cdot m_{2} \cdot l_{1} \cdot r_{2} \cdot \dot{\theta}_{1}^{2} \cdot \sin \theta_{1} \cdot \cos \theta_{1} \cdot \cos \theta_{2} \\
+m_{2} \cdot l_{1} \cdot r_{2} \cdot \dot{\theta_{1}} \cdot \dot{\theta_{2}} \cdot \sin ^{2} \theta_{1} \cdot \sin \theta_{2} \\
+m_{2} \cdot l_{1} \cdot r_{2} \cdot \dot{\theta_{1}} \cdot \dot{\theta_{2}} \cdot \cos ^{2} \theta_{1} \cdot \sin \theta_{2}+I_{2} \cdot \dot{\theta}_{2}^{2} \\
V_{1}=m_{1} \cdot g_{1} \cdot z_{1}=0 \\
V_{2}=m_{2} \cdot g \cdot z_{2}=m_{2} \cdot g_{2} \cdot r_{2} \cdot \sin \theta_{2}
\end{gathered}
$$

Setelah energi kinetik dan energi potensial dari masing-masing link., maka ditentukan nilai torsi menggunakan persamaan Euler Lagrange. Persamaan (12) dan (13) menunjukkan torsi pada link 1 dan link 2.

$$
\begin{gathered}
\tau_{1}=\frac{\partial}{\partial t}\left[\frac{\partial \mathcal{L}}{\partial \dot{\theta_{1}}}\right]-\frac{\partial \mathcal{L}}{\partial \theta_{1}} \\
=\left(m_{1} \cdot r_{1}{ }^{2}+I_{1}+m_{2} \cdot l_{1}{ }^{2}+m_{2} \cdot r_{2}{ }^{2} \cdot \cos ^{2} \theta_{2}\right. \\
\left.+m_{2} \cdot l_{1} \cdot r_{2} \cdot \sin \theta_{1} \cdot \cos \theta_{1} \cdot \cos \theta_{2}\right) \cdot \ddot{\theta}_{1} \\
+\left(m_{2} \cdot l_{1} \cdot r_{2} \cdot \sin \theta_{2}\right) \cdot \ddot{\theta}_{2}
\end{gathered}
$$




$$
\begin{aligned}
& \quad+\left(2 \cdot m_{2} \cdot l_{1} \cdot r_{2} \cdot \sin \theta_{1} \cdot \sin \theta_{1} \cdot \cos \theta_{2} \cdot \dot{\theta}_{1}^{2}\right. \\
& \left.-2 \cdot m_{2} \cdot l_{1} \cdot r_{2} \cdot \cos \theta_{1} \cdot \cos \theta_{1} \cdot \cos \theta_{2} \cdot \dot{\theta}_{1}^{2}\right) \\
& \tau_{2}=\frac{\partial}{\partial t}\left[\frac{\partial \mathcal{L}}{\partial \dot{\theta_{2}}}\right]-\frac{\partial \mathcal{L}}{\partial \theta_{2}} \\
& =\left(m_{2} \cdot l_{1} \cdot r_{2} \cdot \sin \theta_{2}\right) \cdot \ddot{\theta_{1}}+\left(m_{2} \cdot r_{2}{ }^{2}+\right. \\
& \left.I_{2}\right) \cdot \ddot{\theta_{2}} \\
& \quad=\left(m_{2} \cdot l_{1} \cdot r_{2} \cdot \sin \theta_{2}\right) \cdot \ddot{\theta_{1}}+\left(m_{2} \cdot r_{2}{ }^{2}+\right. \\
& \left.I_{2}\right) \cdot \ddot{\theta}_{2} \\
& +\left(m_{2} \cdot r_{2}{ }^{2} \cdot \sin \theta_{2} \cdot \cos \theta_{2} \cdot \dot{\theta}_{1}^{2}\right. \\
& +2 \cdot m_{2} \cdot l_{1} \cdot r_{2} \cdot \sin \theta_{1} \cdot \cos \theta_{1} \cdot \sin \theta_{2} \cdot \dot{\theta}_{1}^{2} \\
& \left.+m_{2} \cdot l_{1} \cdot r_{2} \cdot \cos \theta_{2} \cdot \dot{\theta_{1}} \cdot \dot{\theta_{2}}\right) \\
& +\left(-m_{2} \cdot g_{2} \cdot r_{2} \cdot \cos \theta_{2}\right)
\end{aligned}
$$

\section{Kendali PD plus gravity}

Pada penelitian ini akan digunakan pengendali Proportional Derivative Plus Gravity (PD plus gravity) seperti yang ditunjukkan oleh persamaan (14).

$$
\tau=K_{P} e+K_{D} \dot{e}+G(q)
$$

Persamaan kalang tertutup untuk vektor ruang keadaan $\left[\begin{array}{ll}\tilde{q}^{T} & \dot{q}^{T}\end{array}\right]^{T}$ dapat ditulis seperti pada persamaan (15) [14].

$$
\frac{d}{d t}\left[\begin{array}{l}
\tilde{q} \\
\dot{q}
\end{array}\right]=\left[\begin{array}{c}
-\dot{q} \\
M\left(q_{d}-\tilde{q}\right)^{-1}\left[K_{P} \tilde{q}-K_{D} \dot{q}-C\left(q_{d}-\tilde{q}, \dot{q}\right) \dot{q}\right]
\end{array}\right]
$$

Untuk membuktikan kendali $P D$ plus gravity adalah stabil, maka digunakan metode Lyapunov langsung dan teorema La Salle. Kandidat fungsi Lyapunov beserta turunannya dapat ditulis dengan persamaan (16) dan (17). Kemudian $M(q) \ddot{q}$ disubstitusi ke dalam persamaan (15), sehingga diperoleh persamaan (18).

$$
\begin{gathered}
V(\tilde{q}, \dot{q})=\frac{1}{2} \dot{q}^{T} M(q) \dot{q}+\frac{1}{2} \tilde{q}^{T} K_{P} \tilde{q} \\
\dot{V}(\tilde{q}, \dot{q})=\dot{q}^{T} M(q) \ddot{q}+\frac{1}{2} \dot{q}^{T} M(q) \dot{q}+\tilde{q}^{T} K_{P} \dot{q} \\
\dot{V}(\tilde{q}, \dot{q})=-\left[\begin{array}{c}
\tilde{q} \\
\dot{q}
\end{array}\right]^{T}\left[\begin{array}{cc}
0 & 0 \\
0 & K_{D}
\end{array}\right]\left[\begin{array}{c}
\tilde{q} \\
\dot{q}
\end{array}\right] \leq 0
\end{gathered}
$$

Fungsi $V(\tilde{q}, \dot{q})$ bernilai globally positive definite saat energi kinetik bernilai positive definite pada $\dot{q} . K_{P}$ juga merupakan matriks positive definite. Bentuk kuadratik $\tilde{q}^{T} K_{P} \tilde{q}$ merupakan sebuah fungsi positive definite dari $\tilde{q}$.
Fungsi $V(\tilde{q}, \dot{q})$ adalah sebuah fungsi Lyapunov saat $\dot{V}(\tilde{q}, \dot{q}) \leq 0$ untuk semua $\tilde{q}$ dan $\dot{q}$ dan akibatnya, origin stabil dan semua solusi $\tilde{q}(t)$ dan $\dot{q}(t)$ adalah bounded.

Teorema La Salle digunakan untuk menganalisis global asymptotic stability dari origin. Langkahnya adalah menentukan nilai $\Omega$ seperti pada persamaan (19).

$$
\begin{aligned}
\Omega & =\left\{x \in \mathbb{R}^{2 n}: V(x)=0\right\} \\
& =\left\{x=\left[\begin{array}{c}
\tilde{q} \\
\dot{q}
\end{array}\right] \in \mathbb{R}^{2 n}: V(\tilde{q}, \dot{q})=0\right\} \\
& =\left\{\tilde{q} \in \mathbb{R}^{n}, \dot{q}=0 \in \mathbb{R}^{n}\right\}
\end{aligned}
$$

$\dot{V}(\tilde{q}, \dot{q})=0$, jika dan hanya jika $\dot{q}=0$. Untuk solusi $x(t)$ dalam $\Omega$ untuk semua $t \geq$ 0 , perlu dan cukup bahwa $\dot{q}(t)=0$ untuk semua $t \geq 0$. Oleh karena itu, nilai $\ddot{q}(t)=0$ untuk semua $t \geq 0$. Dengan ini jika $x(t) \in \Omega$ untuk semua $t \geq 0$, maka

$$
0=M\left(q_{d}-\tilde{q}(t)\right)^{-1} K_{P} \tilde{q}(t)
$$$$
M\left(q_{d}-\tilde{q}(t)\right)^{-1} \text { dan } K_{P} \text { adalah }
$$
definit positif, hasil matriknya adalah non singular. Hal ini menyiratkan bahwa $\tilde{q}(t)=0$ untuk semua $t \geq 0$ dan oleh karena itu, $\left[\begin{array}{ll}\tilde{q}(0)^{T} & \dot{q}(0)^{T}\end{array}\right]^{T}=0 \in \mathbb{R}^{2 n} \quad$ adalah satusatunya kondisi awal pada $\Omega$ dimana $x(t) \in \Omega$ untuk semua $t \geq 0$. Berdasarkan teorema La Salle, hal ini cukup untuk membangun global asymptotic stability dari origin, $\left[\begin{array}{ll}\tilde{q}^{T} & \dot{q}^{T}\end{array}\right]^{T}=$ $0 \in \mathbb{R}^{2 n}$

Dalam merancang kendali PD plus gravity perlu ditentukan persamaan error untuk link 1 dan link 2. Untuk mempermudah dalam hal komputasi, maka dibuat persamaan (21) dan (22) sebagai asumsi.

$$
\begin{aligned}
& \dot{x_{1}}=\theta_{1 d}-\theta_{1 a} \\
& \dot{x_{2}}=\theta_{2 d}-\theta_{2 a}
\end{aligned}
$$

Dengan mengintegrasikan persamaan (21) dan (22) ke dalam persamaan (1) dan (14) sehingga diperoleh persamaan posisi dari perangkat pengatur posisi sumber ion DECY-13 untuk tiap link seperti yang terlihat pada persamaan (23).

$$
\left[\begin{array}{c}
\ddot{\theta}_{1} \\
\ddot{\theta}_{2}
\end{array}\right]=M(q)^{-1}\left(-N(q, \dot{q})+\left[\begin{array}{l}
K_{P_{1}}\left(\theta_{1 d}-\theta_{1 a}\right)-K_{D_{1}} \dot{\theta_{1 a}} \\
K_{P_{2}}\left(\theta_{2 d}-\theta_{2 a}\right)-K_{D_{2}} \dot{\theta_{2 a}}
\end{array}\right]\right)
$$

\section{HASIL DAN PEMBAHASAN}

\section{Perhitungan parameter input}

Bahan yang digunakan untuk link 1 adalah Cast Carbon yang memiliki densitas sebesar $7.800 \mathrm{~kg} / \mathrm{m}^{3}$. Link 1 memiliki panjang (l1) dan diameter link 1 masing-masing adalah 
0,3 m dan 0,062 m. Besar massa link 1 ditunjukkan oleh persamaan (24).

$$
\begin{aligned}
m_{1} & =7.800 \mathrm{~kg} / \mathrm{m}^{3} \cdot\left(3,14 \cdot\left(\frac{0,062}{2}\right)^{2} \cdot 0,3\right) \mathrm{m}^{3} \\
& =7,061 \mathrm{~kg}
\end{aligned}
$$

Link 2 terdiri dari tiga bagian yaitu saluran gas $H_{2}$, pegangan sumber ion dan sumber ion. Saluran gas $\mathrm{H}_{2}$ terbuat dari tembaga dan memiliki diameter yang relatif sangat kecil. Diameter saluran gas $\mathrm{H}_{2}<<$ diameter pegangan sumber ion maupun diameter sumber ion, sehingga saluran gas $\mathrm{H}_{2}$ tidak menjadi salah satu parameter penghitungan massa link 2 .

Pegangan sumber ion memiliki dua ukuran (volume) yang berbeda, namun menggunakan bahan yang sama yaitu Cast Carbon. Diameter pegangan sumber ion yaitu $0,12 \mathrm{~m}$ dan $0,18 \mathrm{~m}$. Dari data tersebut, nilai massa pegangan sumber ion dapat dihitung seperti persamaan (25).

$$
\begin{gathered}
m_{p s}=7.800 \mathrm{~kg} / \mathrm{m}^{3}\left(3,14 \cdot\left(\frac{0,12}{2}\right)^{2} \cdot 0,205\right. \\
\left.+3,14 \cdot\left(\frac{0,18}{2}\right)^{2} \cdot 0,02\right) \mathrm{m}^{3}
\end{gathered}
$$$$
=22,0428 \mathrm{~kg}
$$

Bagian sumber ion terbuat dari tembaga yang memiliki densitas sebesar $8.900 \mathrm{~kg} / \mathrm{m} 3$. Sumber ion memiliki diameter $0,13 \mathrm{~m}$ dan 0,07 $\mathrm{m}$. Dari data tersebut, nilai massa sumber ion dapat dihitung seperti persamaan (26).

$$
\begin{aligned}
m_{s}= & 8.900 \mathrm{~kg} / \mathrm{m}^{3} \cdot\left(3,14 \cdot\left(\frac{0,13}{2}\right)^{2} \cdot 0,012\right. \\
& \left.+3,14 \cdot\left(\frac{0,07}{2}\right)^{2} \cdot 0,703\right) \mathrm{m}^{3} \\
= & 25,48326 \mathrm{~kg}
\end{aligned}
$$

Dari nilai massa pegangan sumber ion dan massa sumber ion, maka besarnya massa link 2 dapat dilihat pada persamaan (27).

$$
\begin{aligned}
m_{2} & =22,0428 \mathrm{~kg}+25,48326 \mathrm{~kg} \\
& =47,53 \mathrm{~kg}
\end{aligned}
$$

Besarnya momen inersia dari link 1 ditentukan oleh persamaan (28). Link 1 akan diletakkan pada sepertujuh dari panjang link 2 seperti yang terlihat pada Gambar 4. Berdasarkan Gambar 4, besarnya momen inersia link 2 dapat ditentukan seperti persamaan (29)

$$
I_{1}=\frac{1}{2} \cdot m_{1} \cdot R_{1}^{2}
$$

$$
I_{2}=\frac{1}{12} m_{2} L^{2}+\frac{1}{49} m_{2} L^{2}=\frac{61}{588} m_{2} L^{2}
$$

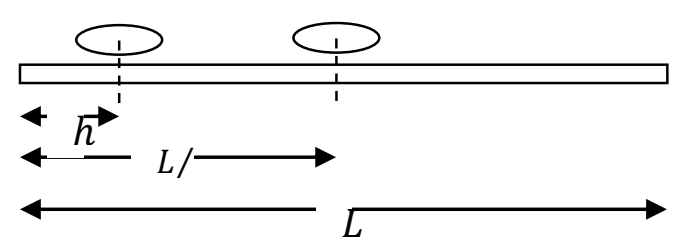

Gambar. 4. Link 2

\section{Hasil simulasi}

Pada frekuensi $0,025 \mathrm{~Hz}$, tanggapan kendali posisi perangkat pengatur posisi sumber ion DECY-13 menggunakan pengendali $P D$ plus gravity masih mengalami osilasi, baik pada link 1 maupun link 2 seperti terlihat pada Gambar 5 dan Gambar 6. Gambar 5 dan Gambar 6 merupakan tanggapan kendali posisi $P D$ plus gravity dengan frekuensi $0,025 \mathrm{~Hz}-0,1 \mathrm{~Hz}$ pada perangkat pengatur posisi sumber ion DECY-13 link 1 dan link 2.

Setelah frekuensi dinaikkan $0,05 \mathrm{~Hz}$ hingga $0,1 \mathrm{~Hz}$, tanggapan dengan pengendali $P D$ plus gravity relatif lebih baik dibandingkan dengan frekuensi dibawahnya $(<0,05 \mathrm{~Hz})$. Efek eliminasi gravitasi yang dilakukan dengan cara penambahan nilai gravitasi pada sistem, menyebabkan tidak tejadi osilasi pada link 1 dan link 2. Penambahan frekuensi menyebabkan rise time semakin cepat yaitu dari 19,6521 detik menjadi 9,8322 detik untuk link 1 dan 20,758 detik menjadi 10,3855 detik. Namun overshoot memiliki nilai yang tidak jauh berbeda yaitu antara 57,7158 \% hingga 57,7731\% untuk link 1 dan 48,835 \% hingga 48,8732\% untuk link 2. Untuk nilai settling time diperkirakan lebih dari 50 detik.

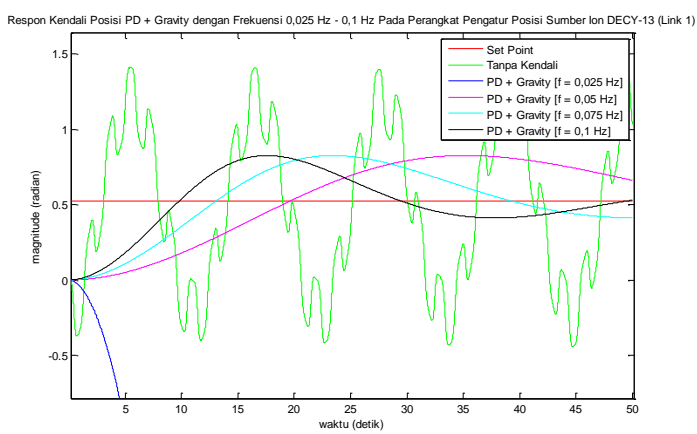

Gambar. 5. Tanggapan kendali posisi $P D$ plus gravity dengan frekuensi $0,025 \mathrm{~Hz}-0,1$ $\mathrm{Hz}$ pada perangkat pengatur posisi sumber ion DECY-13 link 1 


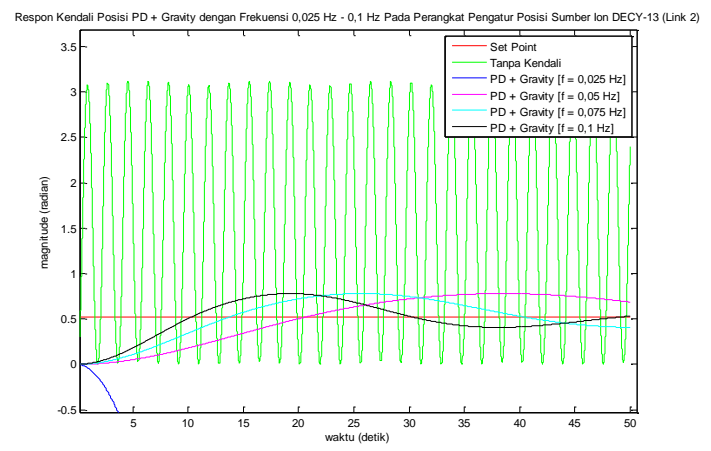

Gambar. 6. Tanggapan kendali posisi $P D$ plus gravity dengan frekuensi $0,025 \mathrm{~Hz}-0,1$ $\mathrm{Hz}$ pada perangkat pengatur posisi sumber ion DECY-13 link 2

Gambar 7 merupakan tanggapan kendali posisi PD dengan frekuensi $0,025 \mathrm{~Hz}-0,1 \mathrm{~Hz}$ pada perangkat pengatur posisi sumber ion DECY-13 link 1, sedangkan Gambar 8 adalah untuk link 2. Dari kedua gambar tersebut diketahui bahwa ketika pengendali PD diaplikasikan ke dalam sistem dengan frekuensi $0,025 \mathrm{~Hz}-0,075 \mathrm{~Hz}$, sistem masih mengalami osilasi, baik pada link 1 maupun link 2. Osilasi menyebabkan nilai overshoot, rise time dan settling time belum bisa diamati. Steady state error pada ketiga frekuensi tersebut memiliki nilai yang relatif besar, baik pada link 1 maupun link 2. ISE yang diperoleh dari kendali PD berkisar antara 5,803e4 hingga 1,804e8 (link 1) dan 2,634e25 hingga 6,966 (link 2). Kendali PD akan menghasilkan IAE bernilai antara $1,844 \mathrm{e} 4$ hingga 1151 (link 1) dan 2,527e4 hingga 362,8 (link 2). Untuk ITAE pada link 1 berkisar antara 5,037e5 sampai 3,638e4, sedangkan pada link 2 bernilai antara $7,34 \mathrm{e} 5$ sampai $1,033 \mathrm{e} 4$.

Nilai steady state error menjadi lebih baik saat frekuensi dinaikkan menjadi $0,1 \mathrm{~Hz}$ yaitu 100,6 (ISE link 1), 18,19 (ISE link 2), 24,43 (IAE link 1), 52,53 (IAE link 2), 286,7 (ITAE link 1) dan 1307 (ITAE link 2). Pada frekuensi ini tidak terjadi osilasi, sehingga dapat diamati tanggapannya baik pada link 1 dan link 2. Pada link 1, nilai overshoot-nya adalah $353,3995 \%$, rise time 2,6437 detik dan settling time bernilai 40,1986 detik. Jika dibandingkan link 1, link 2 memiliki nilai overshoot dan settling time yang lebih tinggi yaitu 465,9855\% dan $>50$ detik, sedangkan nilai rise timerelatif lebih cepat yaitu 0,2587 detik.

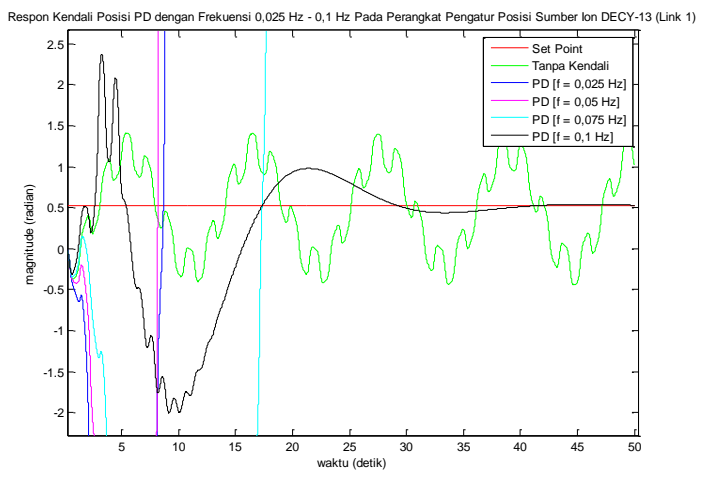

Gambar. 7. Tanggapan kendali posisi PD dengan frekuensi $0,025 \mathrm{~Hz}-0,1 \mathrm{~Hz}-0,1 \mathrm{~Hz}$ pada perangkat pengatur posisi sumber ion DECY-13 link 1

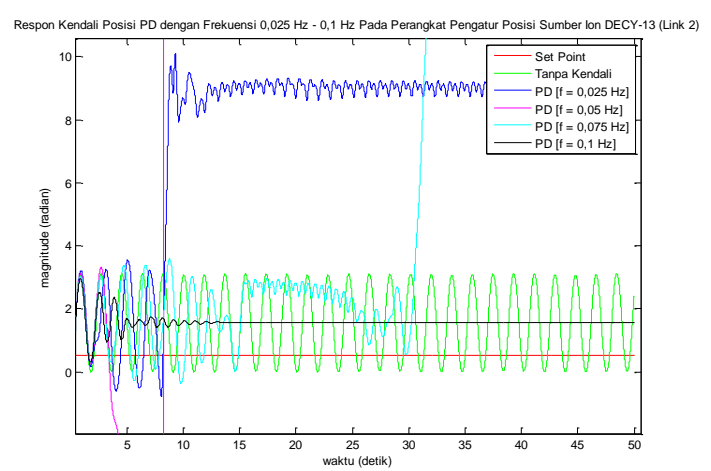

Gambar. 8. Tanggapan kendali posisi PD dengan frekuensi $0,025 \mathrm{~Hz}-0,1 \mathrm{~Hz}$ pada perangkat pengatur posisi sumber ion DECY13 link 2

Pada jangkauan frekuensi $0,025 \mathrm{~Hz}$ hingga $0,1 \mathrm{~Hz}$, kinerja dari kendali $P D$ plus gravity relatif lebih baik dibandingkan dengan kinerja kendali PD. Hal ini dapat dilihat dari steady error untuk link 1 dan link 2 relatif lebih kecil. Nilai steady state error direpresentasikan oleh ISE, IAE dan ITAE. Nilai ISE berkisar antara 64,72 hingga 52,12 (link 1) dan 65,44 hingga 52,51 (link 2), IAE yang diperoleh dari kendali $P D$ plus gravity berkisar antara 13,57 sampai 8,19 (link 1) dan 13,36 sampai 7,837 (link 2). Nilai ITAE bernilai dikisaran 219,9 hingga 133,2 (link 1) dan 207,9 hingga 129,6 (link 2).

Gambar 9 adalah tanggapan kendali posisi PD plus gravity dengan frekuensi $75 \mathrm{~Hz}$ - $750 \mathrm{~Hz}$ pada perangkat pengatur posisi sumber ion DECY-13 link 1, sedangkan tanggapan kendali posisi PD dengan frekuensi $75 \mathrm{~Hz}-750 \mathrm{~Hz}$ pada perangkat pengatur posisi sumber ion DECY-13 link 1 terlihat pada Gambar 10. Ketika frekuensi divariasi antara 75 
$\mathrm{Hz}-750 \mathrm{~Hz}$ dan diaplikasikan untuk kendali PD dan PD plus gravity frekuensi $75 \mathrm{~Hz}-750$ $\mathrm{Hz}$ pada perangkat pengatur posisi sumber ion DECY-13 link 1, dihasilkan tanggapan kendali posisi yang lebih baik sebanding dengan penambahan frekuensi. Dengan adanya kenaikan frekuensi antara $75 \mathrm{~Hz}$ sampai $750 \mathrm{~Hz}$ akan diperoleh nilai $K_{p}$ dan $K_{d}$ akan meningkat, sehingga dihasilkan tanggapan kendali posisi yang lebih baik. Hal ini dapat dilihat pada nilai rise time dan settling time yang semakin cepat, sedangkan overshoot cenderung stabil diantara $57,7349 \%$ sampai $57,754 \%$.

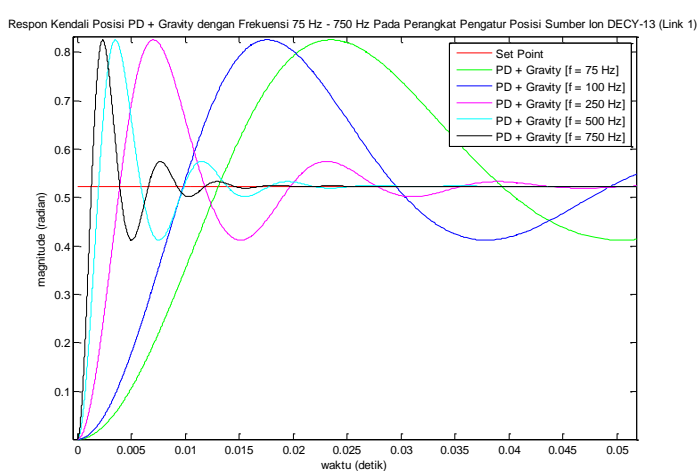

Gambar. 9. Tanggapan kendali posisi $P D$ plus gravity dengan frekuensi $75 \mathrm{~Hz}-750 \mathrm{~Hz}$ pada perangkat pengatur posisi sumber ion DECY-13 link 1

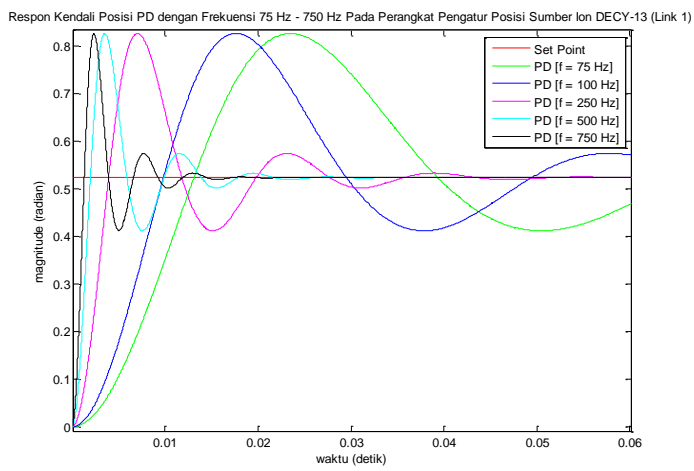

Gambar. 10. Tanggapan kendali posisi PD dengan frekuensi $75 \mathrm{~Hz}-750 \mathrm{~Hz}$ pada perangkat pengatur posisi sumber ion DECY13 link 1

Nilai rise time dan settling time yang diperoleh dari kendali $P D$ plus gravity relatif setara dengan nilai rise time dan settling time yang dihasilkan oleh kendali PD. Rise time dan settling time yang dihasilkan oleh kendali $P D$ plus gravity dan $\mathrm{PD}$ masing-masing berkisar antara 0,0131 detik sampai 1,3102e-3 detik dan 0,1132 detik hingga 0,0113 detik.
Kinerja kendali PD dan $P D$ plus gravity pada jangkauan frekuensi $75 \mathrm{~Hz}-750 \mathrm{~Hz}$ untuk link 1, yang direpresentasikan oleh steady state error yaitu ISE, IAE dan ITAE memiliki nilai yang relatif lebih baik dibandingkan dengan frekuensi dibawahnya $(<75 \mathrm{~Hz})$. Ketika frekuensi dinaikkan dari $75 \mathrm{~Hz}$ hingga $750 \mathrm{~Hz}$, kinerja semakin meningkat yang ditandai dengannilai steady state error bernilai semakin kecil. Kinerja kendali $P D$ plus gravity pada jangkauan frekuensi tersebut setara dengan kinerja kendali PD. Nilai IAE dan ITAE yang dihasilkan berkisar antara 0,01239 hingga 0,001239 dan 0,0003815 sampai 3,814e-6, sedangkan nilai ISE bernilai relatif stabil di kisaran 50.

Gambar 11 adalah tanggapan kendali posisi $P D$ plus gravity dengan frekuensi $75 \mathrm{~Hz}$ - $750 \mathrm{~Hz}$ pada perangkat pengatur posisi sumber ion DECY-13 link 2. Gambar 12 adalah tanggapan kendali posisi PD dengan frekuensi $75 \mathrm{~Hz}-750 \mathrm{~Hz}$ pada perangkat pengatur posisi sumber ion DECY-13 link 2.

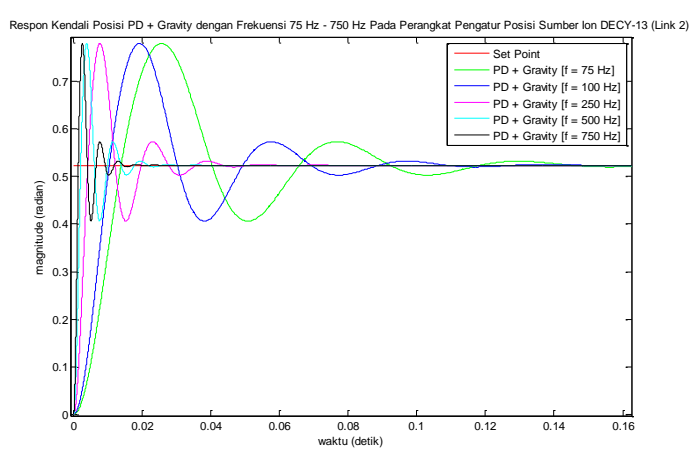

Gambar. 11. Tanggapan kendali posisi $P D$ plus gravity dengan frekuensi $75 \mathrm{~Hz}-750 \mathrm{~Hz}$ pada perangkat pengatur posisi sumber ion DECY-13 link 2

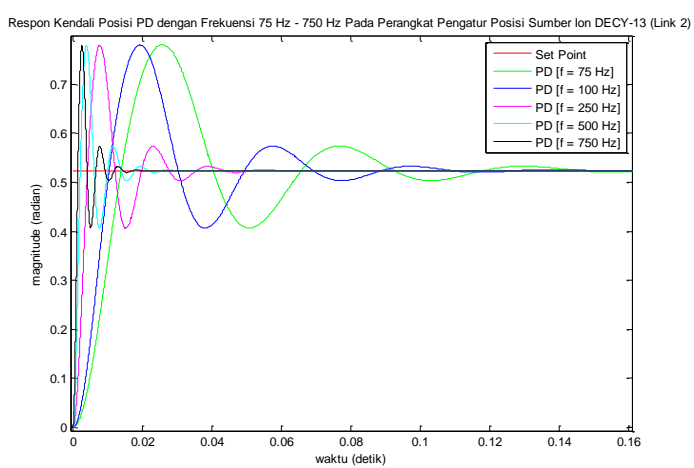

Gambar. 12. Tanggapan kendali posisi PD dengan frekuensi $75 \mathrm{~Hz}-750 \mathrm{~Hz}$ pada perangkat pengatur posisi sumber ion DECY13 link 2 
Dari kedua gambar tersebut terlihat bahwa kinerja kendali PD dan PD plus gravity pada jangkauan frekuensi $75 \mathrm{~Hz}-750 \mathrm{~Hz}$ untuk link 2, yang direpresentasikan oleh steady state error yaitu ISE, IAE dan ITAE memiliki nilai yang relatif lebih baik dibandingkan dengan frekuensi dibawahnya $(<75 \mathrm{~Hz})$. Ketika frekuensi dinaikkan dari $75 \mathrm{~Hz}$ hingga $750 \mathrm{~Hz}$, kinerja semakin meningkat yang ditandai dengan nilai steady state error bernilai semakin kecil. Kinerja kendali $P D$ plus gravity pada jangkauan frekuensi tersebut relatif lebih baik dibandingkan dengan kinerja kendali PD. Nilai IAE yang dihasilkan oleh kendali $P D$ plus gravity berkisar antara 0,01185 sampai 0,001185 , sedangkan IAE yang diperoleh oleh kendali PD bernilai antara 0,04747 hingga 0,001542 . Untuk nilai ITAE yang dihasilkan oleh kendali $P D$ plus gravity berkisar antara 0,0003667 hingga 3,667e-6, sedangkan ITAE yang diperoleh dari kendali PD bernilai antara 0,8944 sampai 0,008948. Nilai ISE yang dibangkitkan oleh kendali PD dan $P D$ plus gravity bernilai relatif stabil di kisaran 50 .

Pada jangkauan frekuensi $75 \mathrm{~Hz}-750 \mathrm{~Hz}$ pada perangkat pengatur posisi sumber ion DECY-13 link 2, nilai overshoot yang dihasilkan oleh kendali PD mengalami penurunan seiring dengan penambahan frekuensi yaitu berkisar antara 49,0451\% hingga $48,8541 \%$, sedangkan overshoot yang dihasilkan oleh kendali $P D$ plus gravity relatif stabil yaitu $48,8541 \%$.

Tanggapan yang dihasilkan oleh kendali posisi PD dan $P D$ plus gravity dengan frekuensi $75 \mathrm{~Hz}-750 \mathrm{~Hz}$ pada perangkat pengatur posisi sumber ion DECY-13 link 2 adalah lebih baik sebanding dengan penambahan frekuensi. Dengan adanya kenaikan frekuensi antara $75 \mathrm{~Hz}$ sampai $750 \mathrm{~Hz}$ akan diperoleh nilai $K_{p}$ dan $K_{d}$ akan meningkat, sehingga dihasilkan tanggapan kendali posisi yang lebih baik. Hal ini dapat dilihat pada nilai rise time dan settling time yang semakin cepat.

Nilai rise time dan settling time yang diperoleh dari kendali $P D$ plus gravity relatif sama dengan nilai rise time dan settling time yang dihasilkan oleh kendali PD. Rise time dan settling time yang dihasilkan oleh kendali $P D$ plus gravity dan PD masing-masing berkisar antara 0,0138 detik sampai 1,3839 e-3 detik dan 0,112 detik hingga 0,0112 detik.

Secara umum tanggapan (overshoot, rise time dan settling time) yang dihasilkan oleh kendali PD dan PD plus gravity pada link 1 dan link 2 tidak ada yang terlalu dominan. Pada saat frekuensi tertentu, kendali PD dan PD plus gravity menghasilkan tanggapan yang relatif sama. Hal ini juga berlaku pada kinerja yang dihasilkan oleh kedua jenis kendali tersebut pada link 1. Hal ini dapat dilihat pada Gambar 13.

Sedikit berbeda dengan kinerja yang dihasilkan oleh kedua jenis kendali tersebut pada link 1 , kinerja yang dihasilkan oleh kendali $P D$ plus gravity memiliki hasil yang lebih baik dibandingkan kendali PD, khususnya IAE dan ITAE.

Frekuensi $500 \mathrm{~Hz}$ dipilih untuk menjadi parameter penalaan $K_{p}$ dan $K_{d}$. Frekuensi ini dipilih, karena dianggap optimal untuk mendapatkan tanggapan yang paling cepat dan kinerja yang paling baik.

\begin{tabular}{|c|c|c|c|c|c|c|}
\hline \multirow{2}{*}{\begin{tabular}{|c|} 
Tanggapan dan \\
Kinerja
\end{tabular}} & \multicolumn{3}{|c|}{ Link 1} & \multicolumn{3}{|l|}{ Link 2} \\
\hline & Frekuensi & $\mathrm{PD}$ & PDG & Frekuensi & PD & PDG \\
\hline \multirow{3}{*}{ Overshoot } & $\mathrm{f} \leq 5 \mathrm{~Hz}$ & & $\overline{\mathrm{V}}$ & f $\angle 500 \mathrm{~Hz}$ & & $\begin{array}{ll}\mathrm{V} \\
\end{array}$ \\
\hline & $5 \mathrm{~Hz}<\mathrm{f}<250 \mathrm{~Hz}$ & $\mathrm{v}$ & & \multirow{2}{*}{$\mathrm{f} \geq 500 \mathrm{~Hz}$} & \multirow{2}{*}{$\mathrm{v}$} & \multirow{2}{*}{$\mathrm{v}$} \\
\hline & $\mathrm{f} \geq 250 \mathrm{~Hz}$ & $\mathrm{v}$ & $\mathrm{v}$ & & & \\
\hline \multirow{2}{*}{ Rise time } & $\mathrm{f} \leq 10 \mathrm{~Hz}$ & & $\mathrm{v}$ & $\mathrm{f}<75 \mathrm{~Hz}$ & $\mathrm{v}$ & \\
\hline & $f>10 \mathrm{~Hz}$ & $\mathrm{v}$ & $\mathrm{v}$ & $\mathrm{f} \geq 75 \mathrm{~Hz}$ & $\mathrm{v}$ & $\mathrm{v}$ \\
\hline \multirow{3}{*}{ Settling time } & $\mathrm{f}<50 \mathrm{~Hz}$ & $\mathrm{v}$ & & $\mathrm{f} \leq 25 \mathrm{~Hz}$ & & $\mathrm{v}$ \\
\hline & \multirow{2}{*}{$\mathrm{f} \geq 50 \mathrm{~Hz}$} & \multirow{2}{*}{$\mathrm{v}$} & \multirow[b]{2}{*}{$\mathrm{v}$} & $25 \mathrm{~Hz}<\mathrm{f}<250 \mathrm{~Hz}$ & $\mathrm{v}$ & \\
\hline & & & & $\mathrm{f} \geq 250 \mathrm{~Hz}$ & $\mathrm{v}$ & $\mathrm{v}$ \\
\hline \multirow{3}{*}{ ISE } & $\mathrm{f} \leq 0,1 \mathrm{~Hz}$ & & $\mathrm{v}$ & $\mathrm{f} \leq 0,05 \mathrm{~Hz}$ & & $\mathrm{v}$ \\
\hline & $0,1 \mathrm{~Hz}<\mathrm{f}<7,5 \mathrm{~Hz}$ & $\mathrm{v}$ & & $0,05 \mathrm{~Hz}<\mathrm{f}<250 \mathrm{~Hz}$ & $\mathrm{v}$ & \\
\hline & $\mathrm{f} \geq 7,5 \mathrm{~Hz}$ & $\mathrm{v}$ & $\mathrm{v}$ & $\mathrm{f} \geq 250 \mathrm{~Hz}$ & $\mathrm{v}$ & $\mathrm{v}$ \\
\hline \multirow{2}{*}{ IAE } & $f<50 \mathrm{~Hz}$ & & $\mathrm{v}$ & \multirow{2}{*}{$\mathrm{f} \leq 10 \mathrm{KHz}$} & & \multirow{2}{*}{$\mathrm{v}$} \\
\hline & $\mathrm{f} \geq 50 \mathrm{~Hz}$ & $\mathrm{v}$ & $\mathrm{v}$ & & & \\
\hline \multirow{2}{*}{ ITAE } & $\mathrm{f}<500 \mathrm{~Hz}$ & & $\mathrm{v}$ & \multirow{2}{*}{$\mathrm{f} \leq 10 \mathrm{KHz}$} & & \multirow{2}{*}{$\mathrm{v}$} \\
\hline & $\mathrm{f} \geq 500 \mathrm{~Hz}$ & $\mathrm{v}$ & $\mathrm{v}$ & & & \\
\hline
\end{tabular}

Gambar. 13. Perbandingan tanggapan dan kinerja PD dan PD plus gravity link 1 dan link 2

Gambar 14 merupakan tanggapan kendali posisi $P D$ plus gravity variasi beban dengan frekuensi $500 \mathrm{~Hz}$ pada perangkat pengatur posisi sumber ion DECY-13 link 1.

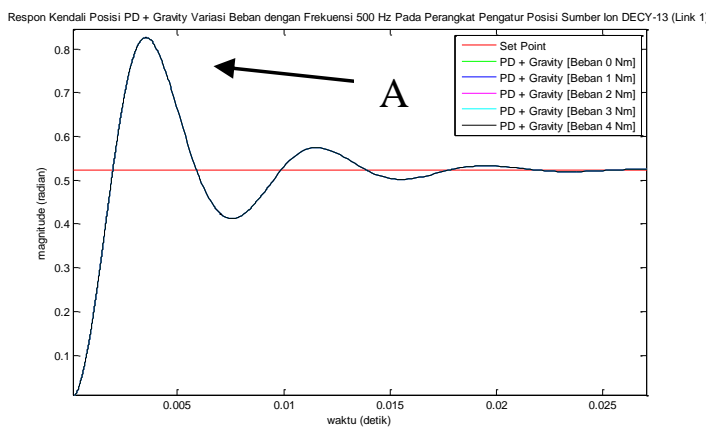


a. Tanggapan kendali posisi $P D$ plus gravity link 1 dengan frekuensi $500 \mathrm{~Hz}$ dengan beban $0 \mathrm{Nm}, 1 \mathrm{Nm}, 2 \mathrm{Nm}, 3 \mathrm{Nm}$ dan $4 \mathrm{Nm}$

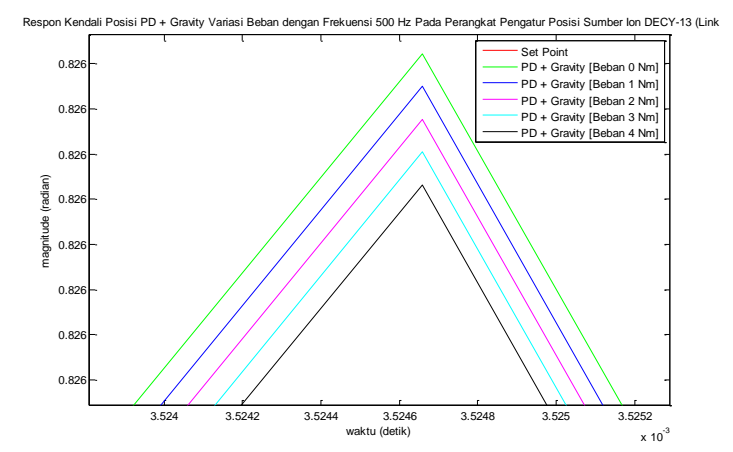

b. Perbesaran A

Gambar. 14. Tanggapan kendali posisi $P D$ plus gravity variasi beban dengan frekuensi $500 \mathrm{~Hz}$ pada perangkat pengatur posisi sumber ion DECY-13 link 1.

Overshoot, rise time, settling time yang dihasilkan oleh kendali $P D$ plus gravity relatif sama dibandingkan dengan overshoot, rise time, settling time yang dihasilkan oleh kendali PD yang masing-masing besarnya $57,754 \%$, 1,9653e-3 detik dan 0,017 detik. Nilai tersebut tidak mengalami perubahan meskipun perangkat tersebut dibebani $1 \mathrm{Nm}$ hingga $4 \mathrm{Nm}$.

Pada frekuensi $500 \mathrm{~Hz}$, tidak ada perbedaan antara kinerja perangkat pengatur posisi sumber ion DECY-13 link 1 yang dihasilkan oleh kendali $P D$ plus gravity dengan kinerja yang dihasilkan oleh kendali PD. Kinerja direpresentasikan oleh ISE, IAE dan ITAE masing-masing memiliki nilai 50, 0,001859 dan 8,581e-6. Saat perangkat tersebut diberi beban antara $1 \mathrm{Nm}$ hingga $4 \mathrm{Nm}$, nilai IAE dan ITAE akan meningkat (kinerjanya menurun) yaitu berkisar antara 0,001864 sampai 0,001879 dan 0,0001354 sampai 0,0005157 , sedangkan nilai ISE-nya memiliki nilai tetap yaitu 50 .

Tanggapan kendali posisi $P D$ plus gravity variasi beban dengan frekuensi $500 \mathrm{~Hz}$ pada perangkat pengatur posisi sumber ion DECY-13 link 2 ditunjukkan oleh Gambar 15.

Sedikit berbeda dengan link 1, kinerja perangkat pengatur posisi sumber ion DECY-13 link 2 (IAE dan ITAE) yang dihasilkan oleh kendali $P D$ plus gravity relatif lebih baik dibandingkan dengan kinerja yang dihasilkan oleh kendali PD. Hal ini berlaku juga saat perangkat diberi beban dari $1 \mathrm{Nm}$ hingga $4 \mathrm{Nm}$. Nilai IAE yang dihasilkan oleh kendali PD plus gravity berkisar antara 0,001777 hingga 0,001798 , sedangkan nilai IAE yang dihasilkan oleh kendali PD berkisar antara 0,002582 hingga 0,002561 . Nilai ITAE yang dihasilkan oleh kendali PD dan PD plus gravity masingmasing berkisar antara 0,02013 sampai 0,01963 dan 8,25e-6 sampai 0,0005154.Untuk nilai ISE, tidak ada perbedaan antara hasil yang diperoleh dari kendali PD dan PD plus gravity yaitu 50 .

Pada frekuensi $500 \mathrm{~Hz}$, tidak ada perbedaan antara tanggapan yang dihasilkan oleh kendali $P D$ plus gravity dengan kendali PD. Hal tersebut juga berlaku saat perangkat tersebut diberi beban antara $1 \mathrm{Nm}$ hingga $4 \mathrm{Nm}$ dimana tidak ada perubahan tanggapan yang diwakili oleh overshoot, rise time dan settling time. Nilai overshoot, rise time dan settling time masing-masing bernilai 48,8541\%, 2,0759e-3 detik dan 0,0169 detik.

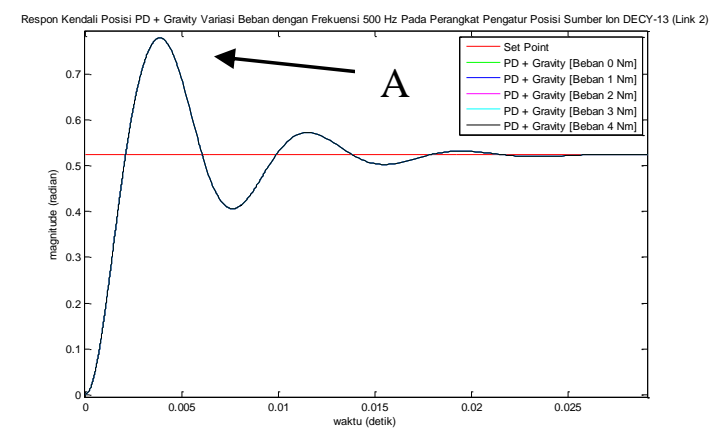

a. Tanggapan kendali posisi $P D$ plus gravity link 2 dengan frekuensi $500 \mathrm{~Hz}$ dengan beban $0 \mathrm{Nm}, 1 \mathrm{Nm}, 2 \mathrm{Nm}, 3 \mathrm{Nm}$ dan $4 \mathrm{Nm}$

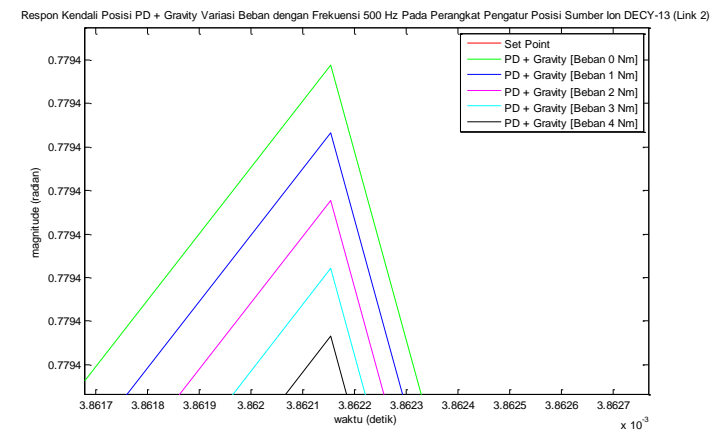

b. Perbesaran A

Gambar. 15. Tanggapan kendali posisi $P D$ plus gravity variasi beban dengan frekuensi $500 \mathrm{~Hz}$ pada perangkat pengatur posisi sumber ion DECY-13 link 2. 


\section{KESIMPULAN}

Dari hasil simulasi dapat disimpulkan bahwa penambahan frekuensi sampai batas tertentu akan menghasilkan tanggapan (rise time dan settling time) yang lebih cepat dan kinerja (steady state error) yang lebih baik.

Penambahan gangguan mengakibatkan tanggapan lebih lambat dan kinerja yang relatif menurun dibandingkan tanpa gangguan.Hal ini berlaku untuk semua link dan semua jenis pengendali (PD dan PD plus gravity).

Selain itu, perangkat pengatur posisi sumber ion DECY-13 dengan pengendali $P D$ plus gravity memiliki tanggapan dan kinerja yang relatif lebih baik dibandingkan dengan pengendali PD, khususnya parameter IAE dan ITAE.Hal ini berlaku untuk semua link dan semua kondisi (tanpa maupun dengan gangguan dan frekuensi).

Frekuensi $500 \mathrm{~Hz}$ dipilih untuk menjadi parameter penalaan $K_{p}$ dan $K_{d}$. Frekuensi ini dipilih, karena dianggap optimal untuk mendapatkan tanggapan yang paling cepat dan kinerja yang paling baik.

\section{UCAPAN TERIMAKASIH}

Penulis mengucapkan terimakasih sebesar-besarnya kepada Bapak Drs. Silakhuddin, M.Si selaku Penanggung Jawab Sub Uskeg Siklotron dan semua anggota tim siklotron atas semua bantuan yang telah diberikan.

\section{DAFTAR PUSTAKA}

1. Anonymous, "Renstra BATAN 20102014," B. T. N. Nasional, Ed., ed. Jakarta, 2010, p. Lampiran 1.

2. Silakhuddin and S. Santosa, "Conceptual Design Study of $13 \mathrm{MeV}$ Proton Cyclotron " Atom Indonesia, vol. 38 No. 1, pp. 7 - 14, 2012.

3. L. Haitao and Z. Tie, "Neural NetworkBased Robust Finite-Time Control for Robotic Manipulator Considering Actuator Dynamics" Robotics and ComputerIntegrated Manufacturing, vol. 29, pp. 301308, 2013.

4. H. Chaudary, V.Panwar, N. Sukavanum and R. Prasad, "Fuzzy PD+I Based Hybrid
Force/Position Control for an Industrial Robot Manipulator," in Third International Conference on Advances in Control and Optimization of Dynamical Systems, Kanpur, India, 2014, pp. 429 - 436.

5. J. Pliego-Jimenez and M.A. Arteaga-Perez, "Adaptive Position/Force Control for Robotic Manipulator in Contact with a Rigid Surface with Uncertain Parameters" Eur. J. Control, vol. 22, pp. 1 - 12, 2015.

6. R. Sharma, P. Gaur and A.P. Mittal, "Performance Analysis of Two-Degree of Freedom Fractional Order PID Controllers for Robotic Manipulator with Payload" ISA Transactions, vol. 58, pp. 279 - 291, 2015.

7. L. Zollo, B. Siciliano, A. D. Luca, and E. Guglielmelli, "PD Control with On-line Gravity Compensation for Robots with Flexible Links," in Proceedings of the European Control Conference, Kos, Greece, 2007, pp. 4365 - 4370..

8. J. Fujishiro, Y. Fukui, and T. Wada, "Finitetime PD Control of Robot Manipulators with Adaptive Gravity Compensation," in IEEE Conference on Control Applications (CCA), Buenos Aires, Argentina, 2016, pp. 898 - 904.

9. C. Murrugarra, J. Grieco, G. Fernandez, and O. D. Castro, "Design of a PD Position Control based on the Lyapunov Theory for a Robot Manipulator Flexible-Link," in 2006 IEEE International Conference on Robotics and Biomimetics Kunming, China, 2006, pp. 890 - 895.

10. D. Zhao and S. Li, "Improvements on Saturating PD with Gravity Compensation Control for Robotic Manipulators," in 7th Asian Control Conference, Hong Kong, China, 2009, pp. 1497 - 1502.

11. O. R. Arroyo, F. R. Cortés, M. A. D. V. Treviño, and S. V. Limon, "Variable Control Gains for P-D controller for Robot Manipulators," in 2015 International Conference on Mechatronics, Electronics and Automotive Engineering, Cuernavaca, Mexico, 2015, pp. 187 - 192.

12. E. Mulyani, A. Hermanto, and P. Anggraita, "Simulasi Lintasan Berkas Proton Siklotron $13 \mathrm{MeV}$ Menggunakan Program PWHEEL," in Pertemuan dan Presentasi Ilmiah Teknologi Akselerator dan Aplikasinya, Yogyakarta, 2012.

13. S. Atmojo and Silakhudin, "Pembuatan dan Pengujian Perangkat Pengatur Posisi 
Sumber Ion untuk Siklotron DECY-13," in Pertemuan Dan Presentasi Ilmiah Teknologi Akselerator dan Aplikasinya 2014, Yogyakarta,2014.

14. R. Kelly, V. S. Davila, and A. Loría, Control of Robot Manipulators in Joint Space. London, United Kingdom: Springer, 2005. 